\title{
Parasynaptic NMDA Receptor Signaling Couples Neuronal Glutamate Transporter Function to AMPA Receptor Synaptic Distribution and Stability
}

\author{
Larissa A. Jarzylo and Heng-Ye Man \\ Department of Biology, Boston University, Boston, Massachusetts 02215
}

\begin{abstract}
At synapses, two major processes occur concomitantly after the release of glutamate: activation of AMPA receptors (AMPARs) to conduct synaptic transmission and activation of excitatory amino acid transporters (EAATs) for transmitter removal. Although crosstalk between the receptors and EAATs is conceivable, whether and how the transporter activity affects AMPAR synaptic localization remain unknown. Using cultured hippocampal and cortical rat neurons, we show that inhibition of glutamate transporters leads to rapid reduction in AMPAR synaptic accumulation and total AMPAR abundance. EAAT inactivity also results in elevated internalization and reduced surface expression of AMPARs. The reduction in AMPAR amount is accompanied by receptor ubiquitination and can be blocked by suppression of proteasome activity, indicating the involvement of proteasome-mediated receptor degradation. Consistent with glutamate spillover, effect of EAAT inhibition on AMPAR distribution and stability is dependent on the activation of parasynaptically localized NR2Bcontaining NMDA receptors (NMDARs). Moreover, we show that neuronal glutamate transporters, especially those localized at the postsynaptic sites, are responsible for the observed effect during EAAT suppression. These results indicate a role for neuron-specific glutamate transporters in AMPAR synaptic localization and stability.
\end{abstract}

\section{Introduction}

The glutamatergic system mediates most of the excitatory synaptic activity in the brain and thus plays a critical role in synaptic transmission and higher brain function. After release from the presynaptic terminal, the clearance of glutamate is achieved through the coordinated activities of glutamate transporters, i.e., excitatory amino acid transporters (EAATs). To date, three EAATs (EAAT1-EAAT3) have been identified in the hippocampus and cerebral cortex (Pines et al., 1992; Storck et al., 1992; Arriza et al., 1994; Rothstein et al., 1994). The glial transporters GLAST/EAAT1 and GLT/EAAT2 are primarily localized to the plasma membrane of astrocytic processes that wrap the synapse (Rothstein et al., 1994; Chaudhry et al., 1995). In contrast, EAAC1/EAAT3 is expressed in the presynaptic and postsynaptic regions of neurons (Rothstein et al., 1994; He et al., 2000, 2001).

Although glial transporters conduct the majority of glutamate reuptake (Rothstein et al., 1996; Peghini et al., 1997; Tanaka et al., 1997), a number of studies suggest that neuronal glutamate transport may play an important role in the dynamics of transmitter clearance (Diamond, 2001; Scimemi et al., 2009). Indeed,

Received June 23, 2011; revised Dec. 21, 2011; accepted Dec. 26, 2011.

Author contributions: L.A.J. and H.-Y.M. designed research; L.A.J. and H.-Y.M. performed research; L.A.J. and H.-Y.M. analyzed data; L.A.J. and H.-Y.M. wrote the paper.

This work was supported in part by National Institutes of Health Grant MH 079407 (H.Y.M.) and a National Alliance for Research on Schizophrenia and Depression Young Investigator Award (H.Y.M.). We thank the Man laboratory members for their helpful discussion.

Correspondence should be addressed to Heng-Ye Man, Department of Biology, Boston University, 5 Cummington Street, Boston, MA 02215. E-mail: hman@bu.edu.

DOI:10.1523/JNEUROSCI.3237-11.2012

Copyright $\odot 2012$ the authors $\quad 0270-6474 / 12 / 322552-12 \$ 15.00 / 0$ in the hippocampal CA1 region, more than half of the synapses do not have an astrocytic process in close proximity, suggesting that neuronal glutamate transport may play a larger role than originally thought in confining released glutamate (Ventura and Harris, 1999). Consistently, EAAT3 knockdown reveals reduced glutamate uptake, neurodegeneration, and epilepsy (Rothstein et al., 1996).

It has been well established that AMPA receptor (AMPAR) trafficking and redistribution serve as fundamental mechanisms for synaptic plasticity and higher brain functions, including learning and memory, but how EAAT function affects glutamate receptors remains unclear. Conceivably, the three key components of the glutamatergic system - the agonist glutamate and its two binding partners (receptors and transporters)-may be functionally coordinated. AMPARs are highly dynamic, trafficking constantly between the plasma membrane and intracellular compartments in a glutamate-dependent manner. The levels of cell-surface AMPARs are regulated by the rate of receptor insertion and internalization, whereas the total amount of AMPARs is determined by a balance between synthesis and degradation. Given that EAAT function is closely coupled with synaptic activity, and AMPAR dynamics and turnover are sensitive to neural activation, EAAT activity may play a role in the regulation of AMPARs.

Here we report that the synaptic localization and protein stability of AMPARs are regulated by glutamate transporter activity. Suppression of EAAT results in AMPAR endocytosis, leading to a reduction in AMPAR synaptic and surface localization. After internalization that is likely initiated by AMPAR ubiquitination, AMPARs are sorted to the proteasome for degradation. We find 
that the EAAT effect on AMPAR trafficking and degradation requires activation of the parasynaptically distributed NR2Bcontaining NMDARs, indicating a role of glutamate spillover during transporter inhibition. Furthermore, inhibition of glial EAAT shows no effect on AMPAR levels, whereas selective knockdown of neuronal glutamate transporter EAAT3, specifically those localized at the postsynaptic domain, induces a reduction in AMPAR expression. These results indicate the existence of functional crosstalk between glutamate transporters and receptors at synaptic sites.

\section{Materials and Methods}

Antibodies and reagents. Antibodies and reagents were obtained from the following commercial sources: anti-GluAlnt (N-terminal), anti-GluA1ct (C-terminal), anti-GluA2nt (N-terminal), and anti-GluN1 were from Millipore; anti-tubulin, anti-pan-p38 MAPK, ifenprodil, $\alpha$-methyl-4carboxyphenylglycine (MCPG), z-leu-leu-leu-al (MG132), 6-cyano-7nitroquinoxaline-2,3-dione (CNQX), dihydrokainic acid (DHK), ammonium chloride, chloroquine, lactacystin, dimethylsulfoxide (DMSO), and 5-fluoro- $2^{\prime}$-deoxyuridine (FDU) were from Sigma-Aldrich; DL-threo$\beta$-benzyloxyaspartic acid (TBOA), ( \pm )-threo-3-methylglutamic acid (T3MG), APV, and MK801 were from Tocris Bioscience; and anti-phosphop38 and 4-(4-fluorophenyl)-2-(4-methylsulfinylphenyl)-5-(4-pyridyl) imidazole (SB203580, SB) were from Cell Signaling Technology. Antiubiquitin (P4D1) was obtained from Santa Cruz Biotechnology, antiPSD-95 from Abcam, anti-EAAT3 from Alpha Diagnostics, and ubiquitin aldehyde PR-11 (PR11) from Biomol.

Neuron cultures. Primary cortical and hippocampal cultures were prepared from E18 rat embryos of either sex. Embryonic brain tissues were digested with papain $\left(1.0 \mathrm{mg} / \mathrm{ml}\right.$ and $5 \mathrm{~mm}$ EDTA in HBSS, $37^{\circ} \mathrm{C}$ for 20 min), washed in trituration buffer $(0.1 \%$ DNase, $1 \%$ ovomucoid $/ 1 \%$ bovine serum albumin in HBSS), and transferred to dishes in plating medium [MEM containing 10\% fetal calf serum, 5\% horse serum (HS), $31 \mathrm{mg}$ of cystine, and 1\% penicillin/streptomycin and L-glutamine mixture $(1 \% \mathrm{P} / \mathrm{S} / \mathrm{G})$; Invitrogen $)]$. Cortical cells $\left(3 \times 10^{6}\right)$ were plated on poly-L-lysine $(0.1 \mathrm{mg} / \mathrm{ml}$; Sigma) coated $60 \mathrm{~mm}$ dishes (Cellstar), and hippocampal cells were plated on five individual nitric-acid-stripped and poly-L-lysine-coated coverslips $\left(0.5-0.7 \times 10^{6}\right.$ cells/coverslip). The cultures were maintained in feeding medium (Neurobasal medium supplemented with $1 \% \mathrm{HS}, 2 \% \mathrm{~B}-27$, and $1 \% \mathrm{P} / \mathrm{S} / \mathrm{G}$; Invitrogen). FDU at $10 \mu \mathrm{M}$ was added on DIV 7 to the medium to curtail glia growth in the culture. Neuronal cultures were fed twice per week by adding $2 \mathrm{ml}$ of feeding medium until use at $\sim 2$ weeks old.

Immunostaining. Coverslips of hippocampal neurons were transferred to 12 -well dishes (Cellstar) containing culture medium. During treatment, the cells were supplemented with $100 \mu \mathrm{M} \mathrm{TBOA}$ at $37^{\circ} \mathrm{C}$ for $60 \mathrm{~min}$ or as indicated, washed in cold artificial cerebral spinal fluid (ACSF) and fixed in $4 \%$ paraformaldehyde $/ 4 \%$ sucrose solution for $10 \mathrm{~min}$ at room temperature. The coverslips were washed in ACSF and permeabilized in a PBS buffer containing $0.3 \%$ Triton X-100. After permeabilization, the cells were washed with ACSF, blocked in $10 \%$ goat serum for $60 \mathrm{~min}$, and incubated with antibodies including the following: GluA1nt (rabbit, 1:500), GluR2nt (mouse, 1:500), NR1Ct (mouse, 1:300), and EAAC1 (rabbit, 1:500) for $2 \mathrm{~h}$ each at room temperature in a 5\% goat serum solution. For GluA1 surface staining, live cells were washed two times with cold ACSF and transferred to cultured medium containing GluA1Nt (rabbit, 1:200) for $7 \mathrm{~min}$ at $37^{\circ} \mathrm{C}$, washed thoroughly with cold ACSF and fixed. Cells were washed and incubated in secondary antibody (Alexa Fluor 555 red anti-rabbit, 1:700 and/or Alexa Fluor 488 green anti-mouse, 1:700, Hoechst, 1:1000) for $1 \mathrm{~h}$ at room temperature, washed, and mounted using Prolong Gold Antifade medium (Invitrogen) for visualization.

Internalization assay. Cells were preincubated with GluAlnt antibody for $7 \mathrm{~min}$ at $37^{\circ} \mathrm{C}$, washed thoroughly with ACSF, and treated with TBOA for $30 \mathrm{~min}$. The remaining antibody on the cell surface was stripped using $(0.5 \mathrm{M} \mathrm{NaCl}, 0.2 \mathrm{M}$ acetic acid) on ice for $10 \mathrm{~min}$ and washed thoroughly with ACSF. Cells were then fixed and permeabilized, followed by incubation with fluorescent secondary antibodies.
Image collection on immunolabeled neurons. Using a Carl Zeiss inverted fluorescent microscope, images were collected with a $63 \times$ oil-immersion objective (numerical aperture 1.4). The exposure time was adjusted manually to ensure the signal intensity within the full dynamic range by using the glow lookup table provided by the Carl Zeiss imaging software. Once an exposure time was established, it was used throughout image collection of all samples.

NIH Image-J software was used for image quantification and analysis. Briefly, GluA1 puncta were selected by applying an intensity threshold to include puncta of 3-30 pixels in size. Both the average intensity and the area of each selected puncta were measured, from which the total puncta intensity (puncta average intensity $\times$ puncta area) was derived. For puncta density, the number of puncta and the corresponding dendrite length were measured respectively to obtain the value of puncta number per unit length.

Transfection of neuronal cultures. Using Lipofectamine 2000 (Invitrogen), DIV 11 hippocampal neurons were transfected with $10 \mathrm{~nm}$ siGENOME rat SLC1A1 siRNA duplex (D-089289-07; Thermo Fisher Scientific) to knockdown EAAT3 or $10 \mathrm{~nm}$ siGENOME nontargeting siRNA \#1 (D-001210-01; Thermo Fisher Scientific) as a control. Cells were cotransfected with GFP or synapsin-YFP to identify transfected neurons and axon terminals. In another set of experiments, hippocampal neurons were transfected with either GFP-tagged wild-type GluA1 or GFP-tagged 4KRGluA1 (GluA1 mutant with all C-terminal lysines changed to arginines).

Western blot analysis of protein abundance. Two-week-old cultured cortical neurons were used for biochemical analysis. Each $60 \mathrm{~mm}$ culture dish was incubated with $100 \mu \mathrm{M}$ TBOA in culture medium for $1 \mathrm{~h}$, washed in cold ACSF, and scraped into modified RIPA buffer $(50 \mathrm{~mm}$ Tris- $\mathrm{HCl}, 1 \% \mathrm{NP}-40,1 \%$ deoxycholate, $0.1 \%$ SDS, and $1: 500$ protease inhibitor cocktail containing: 4-(2-aminoethyl) benzenesulfonyl fluoride (AEBSF), aprotinin, bedysyin, E-64, leupeptin, and pepstatin A; Sigma). Lysates were pulse sonicated 10 times each and centrifuged at $13,000 \mathrm{rpm}$ for $10 \mathrm{~min}$ at $4^{\circ} \mathrm{C}$, and the supernatants were collected and boiled with $6 \times$ SDS-PAGE loading buffer. Samples were submitted to SDS-PAGE separation and immunoprobed with the following antibodies: GluA1ct (rabbit, 1:1000), GluA1nt (rabbit, 1:1000), GluA2nt (mouse, 1:1000), pan-p38 (rabbit, 1:500), phospho-p38 (rabbit, 1:1000), PSD-95 (mouse, 1:500), EAAC1 (rabbit, 1:500), and tubulin (mouse, 1:1000). Films were exposed using a chemiluminescent detection system (GE Healthcare), scanned, and quantified using NIH Image-J.

Isolation of cell-surface AMPARs. Cortical culture neurons were first treated with TBOA, washed in cold ACSF, and incubated in ACSF containing sulfo-NHS biotin conjugate $(1 \mathrm{mg} / \mathrm{ml}$; Pierce) for $10 \mathrm{~min}$ rocking at room temperature, as described previously (Man et al., 2007). Cells were scraped into ice-cold modified RIPA buffer and sonicated. After centrifugation, a small amount of supernatant cell lysates was boiled in $6 \times$ SDS-PAGE sample buffer. To isolate biotinylated surface proteins, 25 $\mu \mathrm{g}(50 \mu \mathrm{l})$ streptavidin beads (Pierce) were added to the remaining supernatant, incubated for $1 \mathrm{~h}$ rotating at $4^{\circ} \mathrm{C}$. The beads were washed several times and boiled in $2 \times$ SDS-PAGE sample buffer before Western blot analysis.

Surface AMPAR degradation assays. Cultured hippocampal neurons were washed two times in cold ACSF and incubated in GluAlnt antibody for $5 \mathrm{~min}$ at $37^{\circ} \mathrm{C}$. The coverslips were then washed six times in cold ACSF and returned to $37^{\circ} \mathrm{C}$ for a time course of incubation with $100 \mu \mathrm{M}$ TBOA. Cells were fixed, permeabilized, and incubated with secondary antibody (Alexa Fluor, 1:700) for $1 \mathrm{~h}$ at room temperature to assess the turnover rate of surface receptors.

Ubiquitination assay. Cultured cortical neurons were preincubated with the NR2B-specific inhibitor ifenprodil $(5 \mu \mathrm{M})$ and the proteasome inhibitor PR11 $(0.5 \mu \mathrm{M})$ for $15 \mathrm{~min}$ at $37^{\circ} \mathrm{C}$, followed by addition of TBOA for $20 \mathrm{~min}$ at $37^{\circ} \mathrm{C}$. Cells were lysed in cold high-stringency RIPA buffer (50 mm Tris-HCl, 1\% NP-40, 1\% deoxycholate, $1 \%$ SDS, and 1:500 protease inhibitor cocktail containing: AEBSF, aprotinin, bedysyin, E-64, leupeptin, and pepstatin A; Sigma) containing ubiquitin aldehyde (1:1000), pulse sonicated 10 times, and centrifuged at 13,000 rpm for $10 \mathrm{~min}$ at $4^{\circ} \mathrm{C}$. Approximately $10 \%$ of the supernatant was collected and boiled with $6 \times$ SDS-PAGE loading buffer to determine total 
protein amount. To isolate AMPARs, GluA1Ct antibody ( $1 \mu \mathrm{g})$ and 20 $\mu \mathrm{g}$ of protein-A agarose beads $(40 \mu \mathrm{l})$ were incubated with the supernatant and rotated for $1 \mathrm{~h}$ at $4{ }^{\circ} \mathrm{C}$. The beads were washed several times and boiled in $2 \times$ SDS-PAGE sample buffer before Western blot analysis.

Statistical analysis. All values were expressed as mean \pm SEM and analyzed using a Student's $t$ test for comparison between two groups or ANOVA with Tukey's post hoc test analysis for multiple groups. Statistical significance is defined as $p<0.05$.

\section{Results}

Suppression of glutamate transporter function reduces GluA1 synaptic expression

During excitatory neurotransmission, glutamate is released from the presynaptic terminal, diffuses across the synaptic cleft, and binds to postsynaptic receptors and transporters. Glial and neuronal glutamate transporters perform the critical task of neurotransmitter reuptake after transmission, thereby preserving the efficacy of the signal, preventing overexcitation of the cells, and providing a means for transmitter recycling. Glutamate receptors and transporters are normally distributed in close proximity to the synapse, and both are able to sense and are activated by glutamate simultaneously. Therefore, crosstalk may exist between these two functional targets of glutamate. To examine the role of glutamate transporter activity on AMPAR synaptic localization, we examined the synaptic localization and expression of AMPARs after application of the nontransportable glutamate transporter inhibitor TBOA in cultured hippocampal and cortical neurons to suppress the activity of all the glutamate transporters (Shimamoto et al., 1998; Jabaudon et al., 1999). Because excess glutamate may lead to excitotoxicity in neurons, we first examined whether TBOA treatment induced cell death under our conditions. Hippocampal cultures were treated with either glutamate $(100 \mu \mathrm{M})$ or TBOA $(100 \mu \mathrm{M})$ for $60 \mathrm{~min}$ and then shifted to normal medium for $5 \mathrm{~h}$ to allow for the potential development of cell death. Propidium iodide labeling showed that, although treatment with glutamate itself induced significant amount of cell death over the course of our assay (cell death, $3 \% \pm 0.12 \%$ in control, $n=850$ cells; $24 \pm 1 \%$ in glutamate treated, $n=675$ cells), no enhanced cell death was observed after TBOA treatment in our cells ( $4 \pm 0.6 \%$ cell death, $n=671$ cells). Using immunocytochemical analysis, we found that, in as early as $10 \mathrm{~min}$ TBOA treatment $(100 \mu \mathrm{M})$, there was a decrease in both intensity (55 \pm $3 \%$ of control) and number (82 $\pm 4 \%$ of control) of GluA1 puncta along the dendritic shaft, which leveled off at $60 \mathrm{~min}$ for puncta intensity ( $50 \pm 6 \%$ of control), as well as puncta density ( $32 \pm 3 \%$ of control) (Fig. $1 A, B$ ), whereas no changes were observed in a control using the vehicle for TBOA (DMSO, 1:1000). To determine whether the decrease in GluA1 synaptic accumulation was through activation of glutamate receptors (Mennerick and Zorumski, 1994; Tong and Jahr, 1994; Diamond and Jahr, 1995), we applied a receptor antagonist cocktail (AC) to block the three major glutamate receptors, including AMPA/kainate receptors (50 $\mu \mathrm{M}$ CNQX), NMDARs (100 $\mu \mathrm{M} \mathrm{APV})$, and metabotropic glutamate receptors (mGluRs) (500 $\mu \mathrm{M}$ MCPG), given $15 \mathrm{~min}$ before and during the 60 min TBOA treatment (Fig. 1C,D). Indeed, by blocking the glutamate receptors with $\mathrm{AC}$, we observed a blockade of the TBOA-induced reduction in GluA1 levels, demonstrating that the TBOA effect was mediated by glutamate receptor activation. To further distinguish the contribution of a specific glutamate receptor, we applied TBOA treatment in the presence of each individual antagonist. Inhibition of either AMPARs or NMDARs was sufficient to block the TBOA effect, whereas blockade of mGluRs had no effect (puncta intensity, $66 \pm 4 \%$ of control; puncta number, $82 \pm 6 \%$ of control) (Fig. 1E,F). In addition to GluA1, similar effects of TBOA were observed on AMPAR GluA2 subunits (Fig. $1 G, H$ ), as well as NR1 subunits of NMDARs (data not shown). Decreases in GluA2 and NR1 levels by TBOA were blocked by preincubation with AC.

\section{Glutamate transporter inactivity leads to AMPAR internalization and degradation}

We observed that glutamate reuptake inhibition caused reduction in synaptic AMPAR accumulation. Because the change could have occurred either in the intraspinal domain or at the cell surface, or both, we wanted to know whether TBOA treatment altered the amount of AMPARs localized at the plasma membrane. Hippocampal neurons were incubated with TBOA over a time course, and the remaining surface AMPARs were labeled with a GluA1 N-terminal antibody (GluA1nt). Indeed, both the intensity $(50 \pm 4 \%$ of control) and number of puncta $(47 \pm 6 \%$ of control) vastly decreased, with a plateau reached at $\sim 30$ min of treatment (Fig. 2A,B). AMPARs are known to be dynamic that undergo constant trafficking vertically between cell surface and intracellular compartments (Malinow and Malenka, 2002; Bredt and Nicoll, 2003; Malenka, 2003; Sheng and Hyoung Lee, 2003; Collingridge et al., 2004; McCormack et al., 2006; Beattie et al., 2010), as well as laterally along the plasma membrane (Borgdorff and Choquet, 2002; Tardin et al., 2003; Ashby et al., 2004; Groc et al., 2004; Adesnik et al., 2005; Ehlers et al., 2007; Heine et al., 2008). In our immunostainings, only the synaptic puncta were selectively analyzed; thus, the decrease in surface puncta intensity might result from lateral diffusion of AMPARs away from the synaptic sites. If that were the case, the total amount of surface receptors should not change. To examine that notion, we performed surface biotinylation assays in cultured cortical neurons to isolate the overall surface AMPARs. We found that both surface and total GluA1 gradually decreased over the time course of TBOA treatment, and, by $2 \mathrm{~h}$ of treatment, both the surface ( $15 \pm$ $8 \%$ of control) and the total ( $49 \pm 17 \%$ of control) had decreased significantly (Fig. 2C,D), indicating a net loss of GluA1 from the cell surface. The decrease in surface GluA1 after glutamate transporter inhibition could be explained by enhanced internalization of surface receptors or decreased insertion of internal receptors. We thus performed a surface internalization assay to determine the contribution of internalization. First, live hippocampal neurons were incubated with a GluAlnt antibody to label surface GluA1, followed by TBOA treatment for $30 \mathrm{~min}$. The internalized receptors were labeled with fluorescent secondary antibody. After TBOA treatment, we observed a marked increase in endocytosed GluAl immunosignals in the soma (133 $\pm 5 \%$ of control) and dendrites (puncta intensity, $115 \pm 2 \%$ of control; puncta number, $144 \pm 6 \%$ of control) (Fig. 2E,F). However, when cells were pretreated with APV $(100 \mu \mathrm{M})$, the TBOA-induced increase in AMPAR internalization was blocked (Fig. 2E,F). These results suggest that glutamate transport inhibition results in an enhanced AMPAR internalization in an NMDAR-dependent manner.

\section{EAAT activity regulates AMPAR ubiquitination and proteasome-mediated degradation}

Interestingly, we found that glutamate transport inhibition resulted in not only a change in AMPAR distribution but also a reduction in total receptor amount (Fig. $2 C, D$ ), indicating the possibility of protein degradation. Previous studies have demonstrated that a proportion of internalized AMPARs are sorted for degradation by different molecular machinery, including the endosomal/lysosomal degradation pathway and the proteasomal 
A

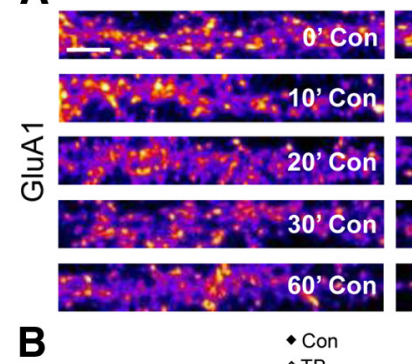

B

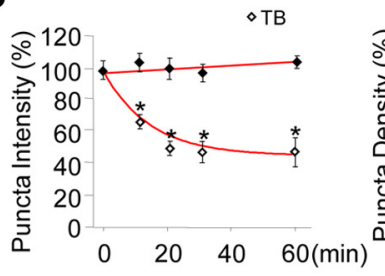

E

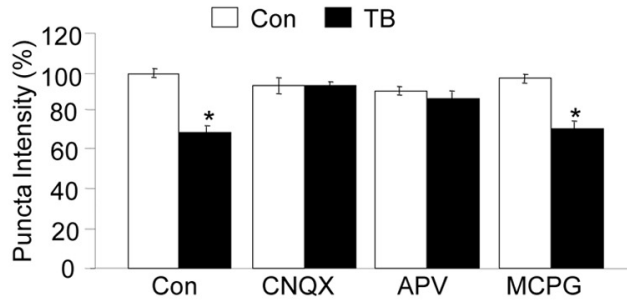

G

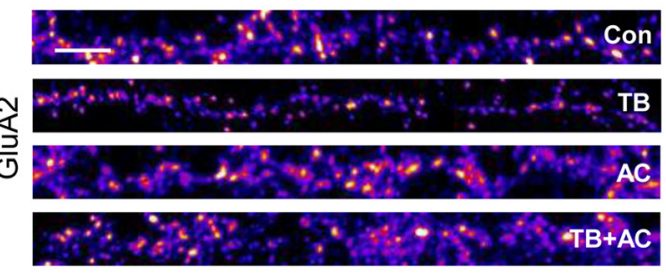

C

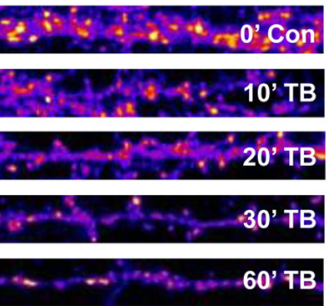

- Con

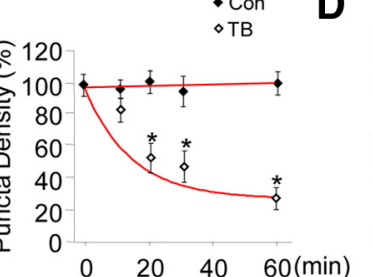

$\mathbf{F}$
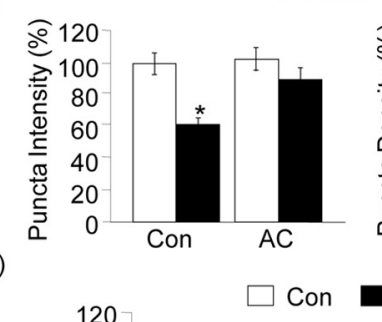

$\mathrm{H}$
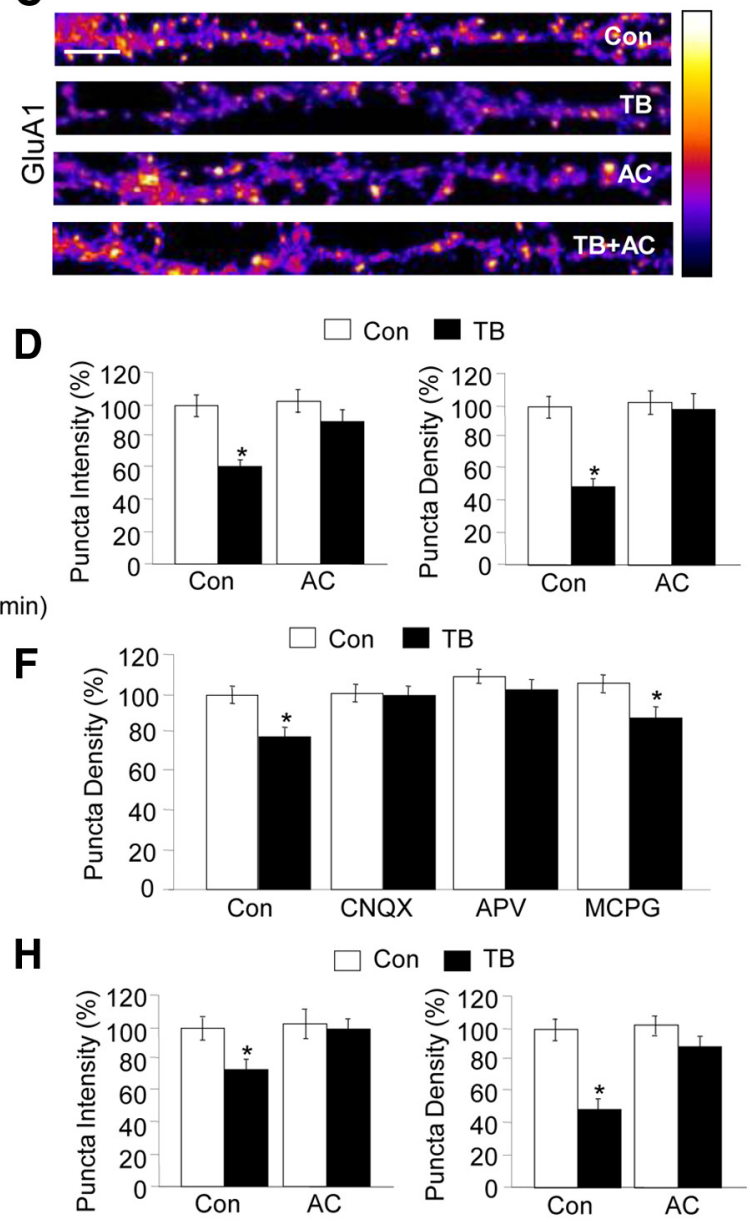

Figure 1. Suppression of EAAT activity leads to a reduction in GluA1 synaptic expression. $\boldsymbol{A}$, Hippocampal neurons were incubated with TBOA (100 $\mu$ M; TB) or DMSO vehicle control (Con) as control for varied periods of time and immunostained with antibodies against the GluA1 subunit under permeant conditions. Representative sections of dendrites show distribution and intensity of GluA1 puncta. $\boldsymbol{B}$, Quantification of both intensity and density of GluA1 puncta along the dendritic shaft for both control and TBOA-treated samples ( $n=11$ cells). $\boldsymbol{C}, \boldsymbol{D}, \boldsymbol{G}, \boldsymbol{H}, \boldsymbol{C e l l s}$ were treated with an $A C$ to block AMPARs (CNQX, $50 \mu \mathrm{M}$ ), NMDARs (APV, $100 \mu \mathrm{m}$ ), and mGluRs (MCPG, $500 \mu \mathrm{m}) 15$ min before and during TBOA treatment ( 60 min) ( $n=12$ cells). Typical dendrites were selected from neurons immunostained with GluA1 (C) or GluA2 (G). The relative intensity is indicated by color coding. $\boldsymbol{E}$, $\boldsymbol{F}$, Cells were treated with TBOA in the presence of individual glutamate receptor antagonists ( $n=13$ cells). ${ }^{*} p<0.05$, two-population, Student's $t$ test. Error bars represent SEM. Scale bars: $\boldsymbol{A}, \boldsymbol{C}, \mathbf{G}, 5 \mu \mathrm{m}$.

pathway (Bingol and Schuman, 2005; Yi and Ehlers, 2007; Schwarz et al., 2010; Lin et al., 2011). To determine whether or not the changes in AMPAR levels were attributable to the lysosomal degradation pathway, we pretreated cells with $\mathrm{NH}_{4} \mathrm{Cl}(50$ $\mu \mathrm{M})$ and chloroquine $(200 \mu \mathrm{M})$ for $15 \mathrm{~min}$, followed by TBOA treatment for $60 \mathrm{~min}$. In the presence of these lysosomal inhibitors, TBOA-induced reduction in GluA1 levels remained (Fig. $3 A, B)$, indicating a negligible role of lysosomes in AMPAR removal. Next, to examine the involvement of proteasomedependent pathway, we pretreated cells for $15 \mathrm{~min}$ with the proteasome-specific inhibitor lactacystin (10 $\mu \mathrm{M})$ or MG132 (10 $\mu \mathrm{M})$. We observed that application of either lactacystin (92 $\pm 5 \%$ of control) or MG132 (103 $\pm 7 \%$ of control) completely blocked the TBOA-induced GluA1 reduction (Fig. $3 A, B$ ). Given that both AMPAR internalization and degradation were observed during EAAT inhibition, we wondered whether the surface receptors were targeted for degradation after internalization. To test this idea, we examined AMPAR turnover though timechasing assays. Surface receptors in hippocampal neurons were first live-labeled with a GluA1 N-terminal antibody and then treated with TBOA over a time course, and all of the prelabeled remaining receptors were visualized by fluorescent secondary an- tibodies under permeant conditions. Under basal conditions without TBOA, a gradual reduction in prelabeled surface GluA1 was observed, indicating the rate of basal turnover. In contrast, in the presence of glutamate transport inhibition, the GluA1 immunosignals showed more dramatic reduction in both receptor puncta intensity (180 min, $50 \pm 2 \%$ of control) and puncta number (180 min, $40 \pm 7 \%$ of control) (Fig. $3 C, D)$, indicating that glutamate transport inhibition resulted in enhanced AMPAR turnover.

To be sorted to the proteasome for digestion, the target proteins are often labeled by ubiquitin, which is enzymatically conjugated to the lysine residue of the substrate molecule. Recent studies including work from our laboratory indicate that AMPARs subject to ubiquitination at the intracellular C-terminal of GluA1 subunits (Burbea et al., 2002; Zhang et al., 2009; Schwarz et al., 2010; Lin et al., 2011; Lussier et al., 2011). This process is mediated by the E3 ligase Nedd4 and leads to a reduction in AMPAR surface expression attributable to facilitated receptor internalization, as well as protein degradation (Schwarz et al., 2010; Lin et al., 2011). Thus, it was possible that the observed changes in AMPAR distribution and degradation during EAAT suppression resulted from receptor ubiquitination. To this end, 


\section{A}
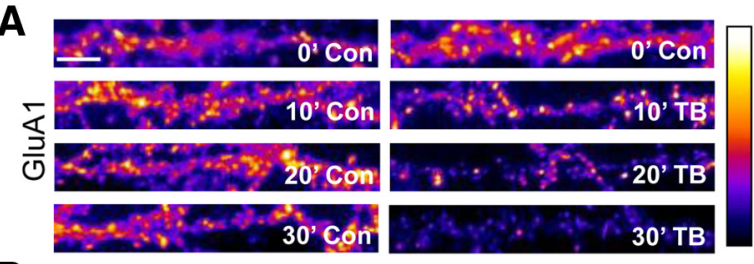

B
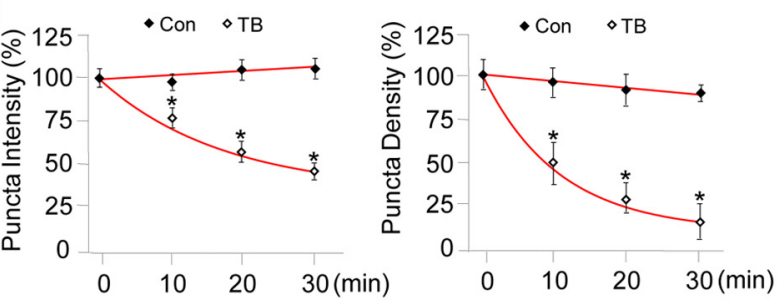

C
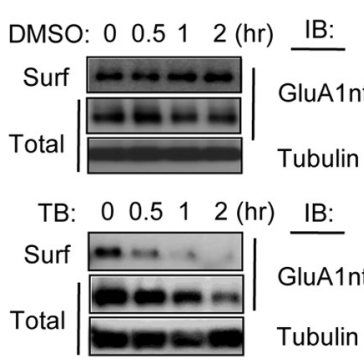

IB
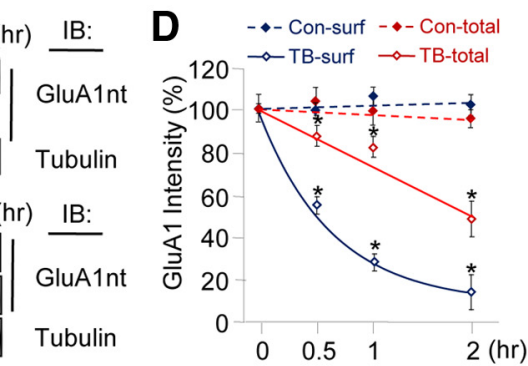
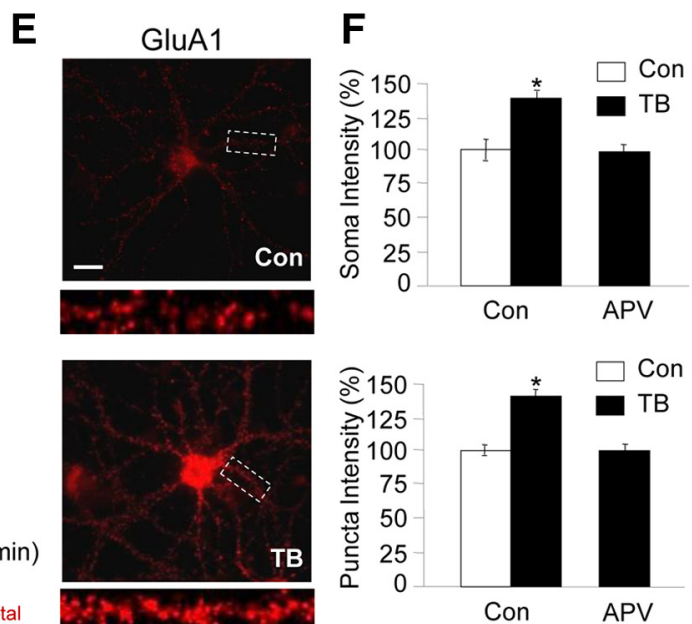

Figure 2. Suppression of EAAT activity causes AMPAR internalization and degradation. $A, B$, Hippocampal neurons were treated over a time course with TBOA or vehicle control (DMSO; Con) and then incubated with antibodies against the GluA1Nt to label surface AMPARs ( $n=12$ cells). $C, D$, In cultured cortical neurons, AMPARs of plasma membrane were isolated by surface biotinylation after TBOA treatment. The protein level of tubulin was probed as an additional control $(n=3)$. IB, Immunoblotting. E, AMPAR internalization assay. Surface AMPARs were live labeled and then treated with TBOA, alone or together with the NMDAR antagonist APV, for $30 \mathrm{~min}$. Control cells were kept in medium for the same time period. Internalized receptors were selectively labeled by a fluorescence secondary antibody (red). A section of dendrite is enlarged for clarity. $\boldsymbol{F}$, Measurement of internalized GluA1 $\left(n=14\right.$ cells). ${ }^{*} p<0.05$, two-population, Student's $t$ test. Error bars represent SEM. Scale bars: $A, 5 \mu \mathrm{m} ; \boldsymbol{E}, 30 \mu \mathrm{m}$.

A

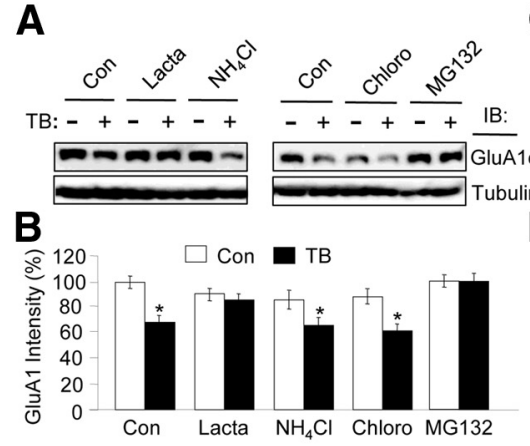

$\mathbf{F}$
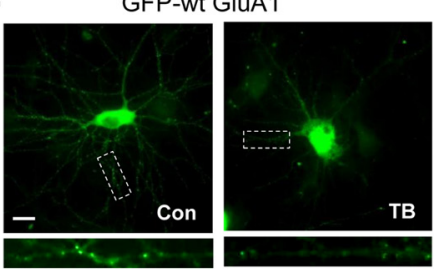

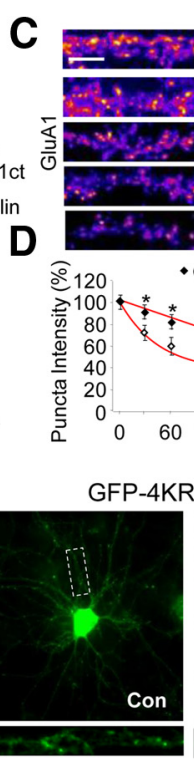

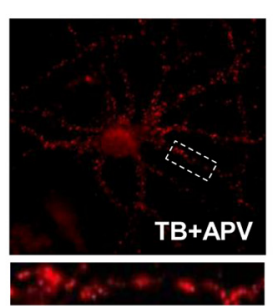

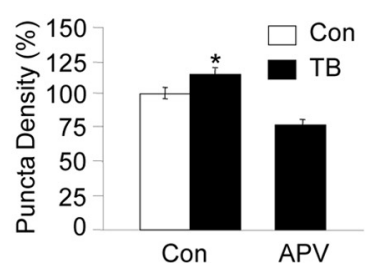

APV 

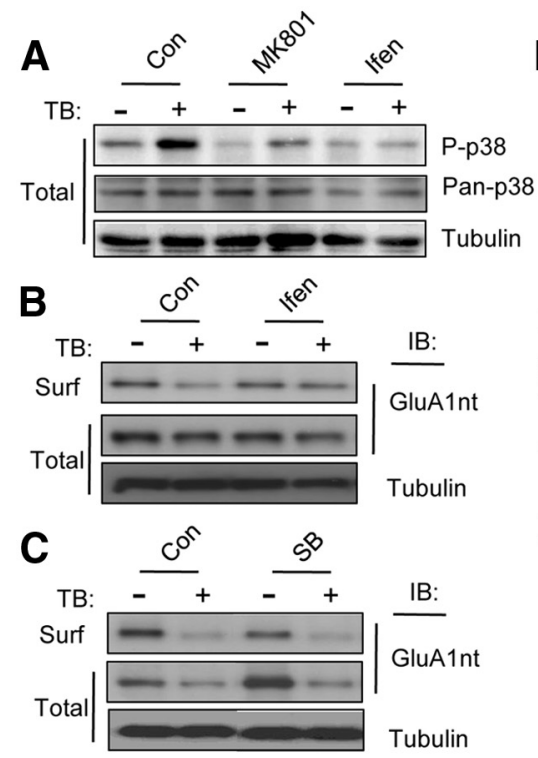

D

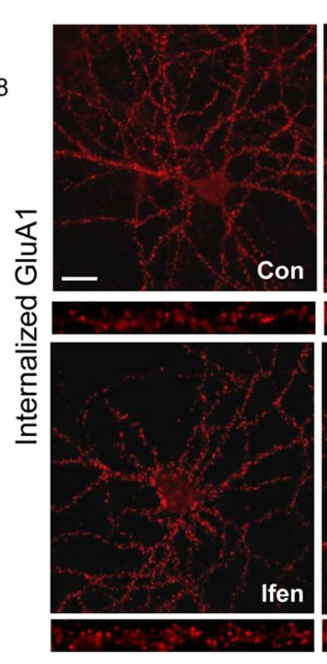

E

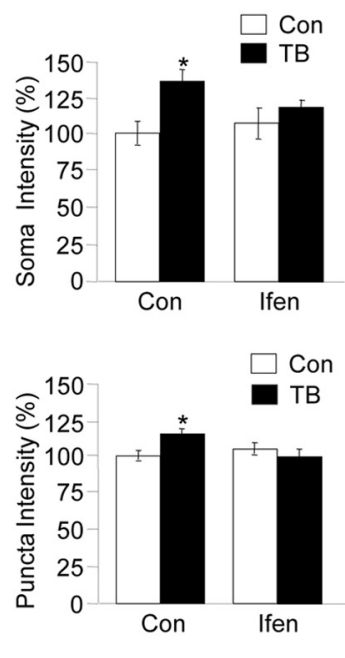

Figure 4. EAAT suppression leads to activation of NR2B-containing NMDARs. A, Cortical neurons were supplemented with NMDAR antagonist MK801 (20 $\mu \mathrm{M})$ for 15 min, followed by 60 min TBOA (TB) treatment. NR2B-specific inhibitor ifenprodil (Ifen, $5 \mu \mathrm{m}$ ) was applied $15 \mathrm{~min}$ before and during TBOA treatment. Western blots were probed with antibodies against phosphorylated p38 (P-p38) or general p38 (Pan-p38) ( $n=3-4$ experiments). B, C, Cortical neurons were pretreated for 15 min with ifenprodil (B) or the p38-selective inhibitor SB (10 $\mu \mathrm{M})(\boldsymbol{C})$, followed by 60 min TBOA treatment. Remaining surface proteins (Surf) were labeled by biotinylation, and both surface and total protein levels were examined ( $n=3-4$ experiments). $\boldsymbol{D}, \boldsymbol{E}$, Internalization assay in cortical neurons treated with TBOA alone or together with ifenprodil $\left(n=12\right.$ cells). ${ }^{*} p<0.05$, two-population, Student's $t$ test. Error bars represent SEM. Scale bar, $30 \mu \mathrm{m}$. Con, Control; IB, immunoblotting.

we pretreated cells with the proteasome inhibitor PR11 for 30 min to block the degradation of ubiquitinated target proteins, followed by treatment with TBOA for $30 \mathrm{~min}$. GluA1 was then immunoprecipitated and probed for ubiquitination. We found that, under basal conditions, the AMPAR ubiquitination signals were minimal, which was not changed by TBOA treatment, indicating low ubiquitination activity or efficient removal of ubiquitinated receptors (Lin et al., 2011). In contrast, during proteasomal activity suppression, TBOA induced a marked increase in the extent of receptor ubiquitination (Fig. 3E), indicating that, after transport inhibition, GluA1 subunits were targeted by the ubiquitin proteasome system (UPS). To further confirm the involvement of receptor ubiquitination in TBOA effect, we analyzed the TBOA effect on GluA1 mutant that contains no intracellular lysine residues (GFP-4KRGluA1). Neurons expressing GFP-tagged wild-type GluA1 (GFP-wtGluA1) or lysine mutant GFP-4KRGluA1 were treated with TBOA for $60 \mathrm{~min}$. Although TBOA induced a marked decrease in GluA1 levels, no changes were observed at GFP-4KRGluA1 (Fig. $3 F, G$ ). These data suggest that, after glutamate transport inhibition, AMPARs are subjected to ubiquitination before their internalization and degradation.

\section{EAAT suppression leads to activation of NR2B-containing NMDARs}

NMDAR activity plays a major role in the regulation of AMPAR trafficking and subcellular distribution (Malinow and Malenka, 2002; Song and Huganir, 2002; Malenka, 2003; Derkach et al., 2007). Consistently, the EAAT inhibition-induced changes in AMPAR dynamics and stability were found to be NMDAR dependent (Figs. $1 C-H, 2 E, F$ ). There are two major subtypes of NMDARs, namely, NR2A-containing and NR2B-containing NMDARs that differ in channel properties, developmental expression patterns, and synaptic localization (Liu et al., 2004; Groc et al., 2007; Lau and Zukin, 2007; Yashiro and Philpot, 2008; Sanz-Clemente et al., 2010). The NR2A subtype is expressed primarily at the central region of a synapse, whereas the NR2B subtype is localized mainly to the edges of synaptic clefts or parasynaptic areas (Lozovaya et al., 2004; Prybylowski et al., 2005). Under conditions of vast amounts of transmitter release and/or reduced transmitter removal, glutamate may leak out of the synaptic cleft and reach the NR2B-NMDARs. We reasoned that, during glutamate transport inhibition, accumulation of glutamate in the synaptic cleft leads to glutamate spillover to the parasynaptic membrane and consequent interaction with NR2BNMDARs. We therefore examined the phosphorylation of p38 MAPK, a known downstream effector of NR2B-NMDARs (Zhu et al., 2002; Izumi et al., 2008). We found that 60 min incubation of cortical neurons with TBOA markedly increased the level of p38 phosphorylation (Fig. 4A), which was completely blocked by ifenprodil, a specific inhibitor agonist NR2B-NMDARs. To confirm that EAAT inhibition indeed resulted in the activation of parasynaptically localized NR2B-NMDARs, we incubated neurons with MK801 $(20 \mu \mathrm{M})$ before TBOA treatment. MK801 is an NMDAR open channel blocker that, when applied under basal conditions, will irreversibly block active NR2A-NMDARs at the inner domain of a synapse. After MK801 incubation and removal, application of TBOA still induced p38 phosphorylation (Fig. 4A), suggesting that, after glutamate transport inhibition, glutamate accumulation resulted in parasynaptic NR2B-NMDAR activation.

Next, we investigated the involvement of parasynaptic NMDARs and p38 signaling in AMPAR surface expression and stability. Neurons were preincubated with ifenprodil to block NR2B or SB $(10 \mu \mathrm{M})$ to block p38 activation (Rouse et al., 1994; Harada and Sugimoto, 1999) and then treated with TBOA (Fig. $4 B, C)$. Surface biotinylation showed that NR2B inhibition blocked both the TBOA-induced surface reduction and degrada- 
tion of GluA1. However, p38 inhibition failed to block the TBOA effect, indicating that the involvement of NR2B-NMDARs was independent of p38 signaling. Next, we investigated whether the activation of NR2B-NMDARs was responsible for the enhanced AMPAR internalization as observed in our previous data (Fig. $2 E, F$ ). As shown in our previous data, TBOA treatment alone induced a vast increase in receptor internalization (soma and puncta intensity, $140 \pm 7$ and $115 \pm 2 \%$ of control, respectively) (Fig. $4 D, E$ ). In contrast, in the presence of ifenprodil, TBOA treatment no longer induced enhanced AMPAR internalization (soma and puncta intensity, $110 \pm 9$ and $97 \pm 2 \%$ of control, respectively). This indicates that NR2BNMDARs may be involved in triggering GluA1 internalization after glutamate accumulation. In addition, consistent with its role in EAAT-dependent AMPAR internalization, NR2B signaling was also required for AMPAR ubiquitination. We pretreated cells with ifenprodil for $15 \mathrm{~min}$ and then treated with both ifenprodil and TBOA for 30 min. Inhibition of NR2B completely blocked the enhanced GluA1 ubiquitination after incubation with TBOA plus the proteasome inhibitor PR11 (Fig. 3E).

\section{Effects of EAAT suppression are} mediated mainly by neuronal glutamate transporter EAAT3

The bulk of glutamate reuptake is believed to be conducted by glial transporters. Because TBOA is a nonselective inhibitor, we then used glial-specific inhibitors to determine the role of glial transport in AMPAR stability. Surprisingly, we found that incubation of cortical neurons with DHK and T3MG, EAAT1 and EAAT2 inhibitors, respectively, failed to induce any changes in AMPAR amount compared with the significant receptor reduction in TBOA-treated cells (Fig. 5A), suggesting that neuronal transporters play a role in AMPAR stability. In hippocampal and cortical neurons, the only neuronal glutamate transporter is EAAT3, which has been shown to be synaptically distributed (Rothstein et al., 1994; He et al., 2000, 2001). Indeed, we found by immunostaining that EAAT3 puncta colocalized with the synaptic marker PSD-95 (data not shown). In our culture preparation, neurons and glia grow in the dish with only "patches" of overlap between the two cell types. In addition, because glia growth has been routinely suppressed by inhibitors in the medium, a large proportion of neurons do not grow in close proximity to glia at all. We thus reasoned that the effects of EAAT inhibition on AMPAR distribution and turnover may be primarily attributable to blockade of neuronal transporters. To examine this notion, we immunostained our cultured hippocampal neurons for both glial fibrillary acidic protein, a glia-specific protein, and PSD-95, a known postsynaptic marker, and found that a large numbers of PSD-95 puncta did not colocalize with astrocytic processes (data not shown). Given that we observe a nearly uniform decrease in
GluA1 levels along the dendritic shaft after glutamate transport inhibition, this suggests that TBOA-induced changes in GluA1 abundance are independent of the close proximity of glial transporters to the synapse. To further evaluate the role of glial transporters, we eliminated $80 \%$ of the glia compared with control by supplement the cells with FDU $(10 \mu \mathrm{M})$ to inhibit glial cell proliferation (data not shown). The reduction in glia cell number resulted in a low level of basal AMPAR expression, probably attributable to a lack of glial-released factors that are known to promote AMPAR expression (Ullian et al., 2004; Pfrieger, 2009; Eroglu and Barres, 2010). When we treated low-glia cultures with TBOA, we observed a decrease in both GluA1 puncta intensity ( $64 \pm 2 \%$ of control) and puncta number $(87 \pm 3 \%$ of control) comparable with the TBOA effects in regular neuronal culture (puncta intensity, $65 \pm 1 \%$ of control; puncta number, $85 \pm 5 \%$ of control) (Fig. $5 B, C$ ). Thus, despite the removal of the majority of the astrocytes in the culture, EAAT inhibition-dependent GluA1 reduction remains the same, suggesting that the TBOA effect is primarily mediated by neuronal transporters.

Because of their synaptic localization, neuronal transporters may regulate synaptic glutamate but have no significant 
A

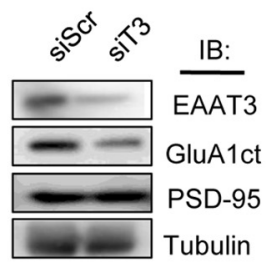

B

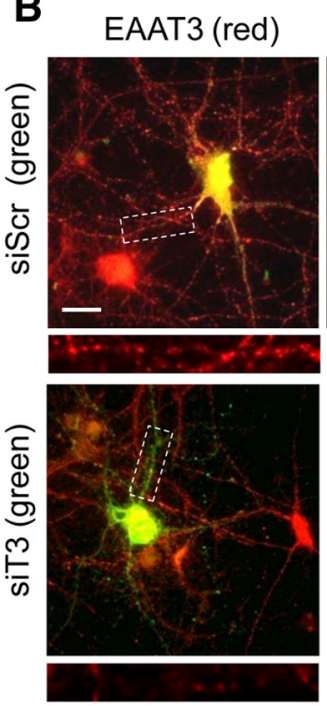

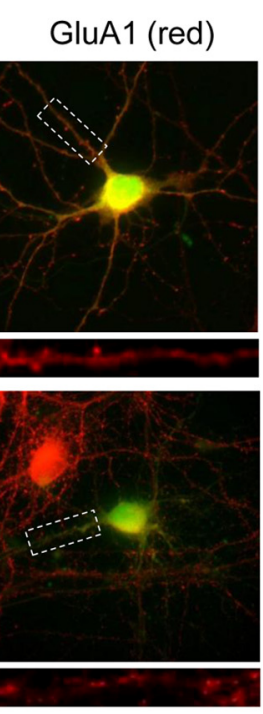

C

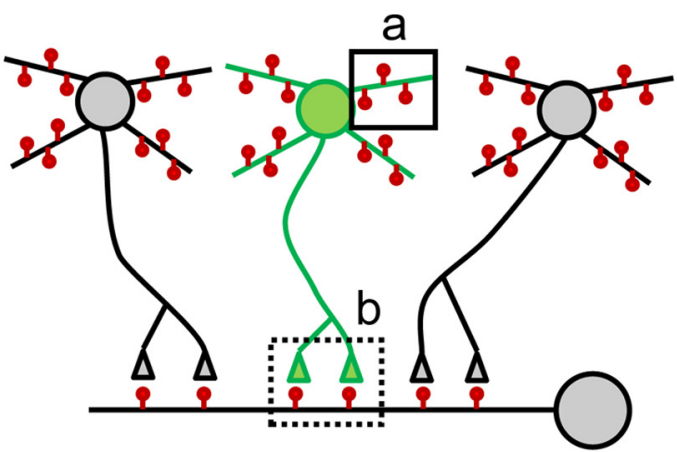

D

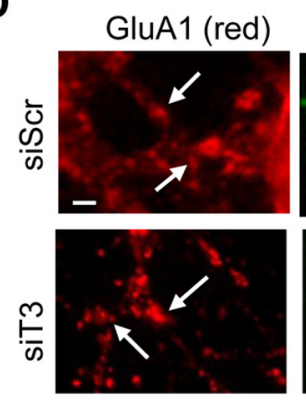

E

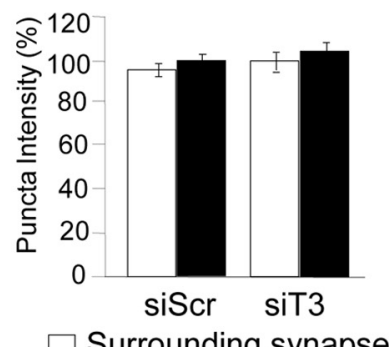

Surrounding synapse

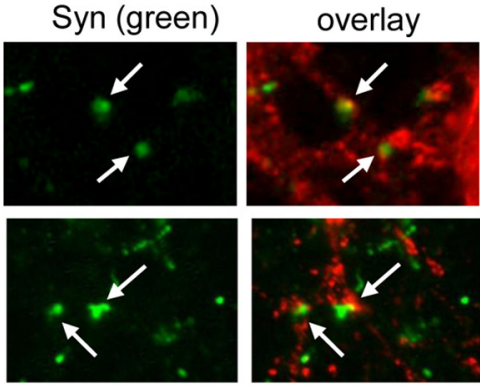

120

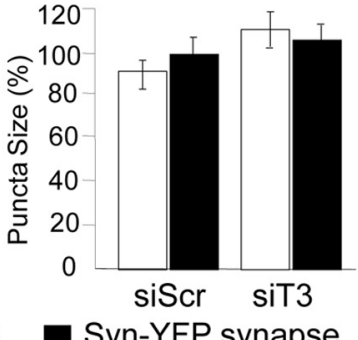

Figure 6. Differential roles of presynaptic and postsynaptic EAAT3. $\boldsymbol{A}$, Western blot showing effect of siRNA-mediated EAATs knockdown on AMPARs abundance ( $n=3-4$ experiments). $\boldsymbol{B}$, Neurons were transfected with EAAT3 siRNA (siT3) or scrambled control siRNA (siscr), together with GFP. Expression of EAAT3 and GluA1 was examined after immunostaining ( $n=20$ cells). $C$, Diagram showing experimental paradigm for selective knockdown of presynaptic or postsynaptic EAATs. A neuron was transfected by EAAT3 siRNA and synapsin-YFP (green), whose axon terminals formed synapses with a nontransfected neuron. In boxed region $\boldsymbol{a}$, only postsynaptic EAAT3 (at the spines of the transfected neuron) was knocked down, whereas in boxed region $\boldsymbol{b}$, only the presynaptic EAAT3 was suppressed by siRNA. D, E, Coverslips were transfected with synapsin-YFP (Syn-YFP) and EAAT3 siRNA or scrambled control siRNA. GluA1 abundance at the synapses that lacked presynaptic EAAT3 (indicated by green terminals) was compared with surrounding synapses ( $n=12$ cells). Arrows indicate synapsin-YFP synapses. ${ }^{*} p<0.05$, two-population, Student's $t$ test. Error bars represent SEM. Scale bars: $\boldsymbol{B}, 30 \mu \mathrm{m} ; \boldsymbol{D}, 2 \mu \mathrm{m}$.

role in ambient extracellular glutamate concentration. In contrast, the wide spread and more dominant glial transporters can regulate both synaptic and ambient extracellular glutamate in the medium. If the TBOA effect is mediated by glial EAATs, glutamate accumulation in the medium should be sufficient to induce these changes. To distinguish these possibilities, cultures were incubated in various amounts of medium and treated with the same concentration of TBOA. If the TBOA effect was caused by an increase in ambient glutamate in the culture medium, we expected that the TBOA effect would be diluted by high volume of medium. In contrast, if glutamate transport inhibition resulted only in the local accumulation of glutamate in the synaptic cleft, changing the amount of medium should have no effect on TBOA-induced AMPAR reduction. When cells were treated with $100 \mu \mathrm{M}$ TBOA in $0.5,1$, and $2 \mathrm{ml}$ of medium, respectively, we found that the amount of GluA1 reduction remained essentially the same (Fig. $5 D, E$ ), suggesting that glutamate transport inhibition results in a local accumulation of glutamate at the synaptic sites, consistent with a role of neuronal glutamate transporters.

To further assess the contribution of neuronal glutamate transport in our culture system, we examined the effects of
EAAT3 knockdown through overexpression of an EAAT3specific siRNA. In cultured cortical neurons, transfection of siRNA lead to a significant reduction in EAAT3 abundance, accompanied by a reduction in GluA1 levels but not PSD-95 or tubulin protein amount, indicating the specific removal of AMPARs (Fig. 6A). To examine the effect of EAAT3 knockdown on synaptic AMPARs, we performed immunostaining in neurons transfected with siRNA together with GFP. Compared with the scrambled control siRNA, EAAT3 siRNA indeed suppressed the expression of the neuronal transporter ( $21 \pm 3 \%$ of control). Importantly, in neurons expressing the EAAT3 siRNA, synaptic accumulation of the GluA1 subunit was significantly reduced ( $84 \pm 4 \%$ of control) (Fig. $6 B$ ). This result indicates that neuronal transporter activity plays an important role in the distribution and stability of synaptic AMPARs.

\section{Differential effects of presynaptically and postsynaptically} localized EAAT3

Neuronal glutamate transporters are localized at both presynaptic and postsynaptic membrane, but the relative contribution and abundance of either population of transporters remains unclear (Rothstein et al., 1994; He et al., 2000, 2001). To distinguish the 
relative contribution of the differentially distributed EAAT3, EAAT3 siRNA was transfected with presynaptic marker protein synapsin-YFP. Because of a low transfection rate and the large number of inputs an individual neuron receives, at synapses on the transfected neuron, usually only postsynaptic EAAT3 is removed by siRNA. In contrast, at a synapse formed between an axon terminal from a transfected neuron (identified by synapsinYFP puncta) and a nontransfected neuron, only the presynaptic EAAT3 is knocked down (Fig. 6C) (Hou et al., 2008). Using 12d-old hippocampal neurons, we cotransfected the EAAT3specific siRNA along with synapsin-YFP and immunostained GluA1 $2 \mathrm{~d}$ after transfection. GluA1 puncta that colocalized with synapsin-GFP were compared with that of the neighboring synapses along the same dendritic shaft that received presynaptic input from nontransfected neurons (Fig. 6D,E). Interestingly, GluA1 intensity at the YFP synapses (103 $\pm 4 \%$ of control) showed no difference from the neighboring control sites $(100 \pm$ $4 \%$ of control) (Fig. $6 D, E$ ). As mentioned above (Fig. $6 B$ ), AMPARs were reduced at synapses on the transfected neuron itself, in which only the postsynaptic EAAT3 was removed. Together, these data indicate that EAAT3 at the postsynaptic, but not the presynaptic, domain plays a key role in the control of AMPAR accumulation.

\section{Discussion}

Our study indicates that glutamate transporter activity regulates AMPAR synaptic accumulation and stability. After glutamate transport inhibition, glutamate presumably diffuses to the edges of synaptic cleft, in which it binds to parasynaptically localized NMDARs. Stimulation of NR2B-NMDARs leads to AMPAR ubiquitination, internalization, and proteasome-mediated degradation. Furthermore, we show that the effect of EAAT suppression on AMPAR reduction is mediated mainly by the neuronal transporter EAAT3. Inhibition of glial transporters has no effect on AMPARs, and the reduction in AMPARs after EAAT inhibition remains in the absence of glia in the culture, suggesting a minimal role of glial glutamate transporters. Moreover, the knockdown of EAAT3 by siRNA caused similar effects on AMPAR expression to that of EAAT inhibition. In addition, we show that the population of EAAT3 at the postsynaptic, rather than the presynaptic, site is responsible for AMPAR regulation. These findings indicate that the neuronal glutamate transporters, which are traditionally considered to be negligible in glutamate removal, may have an important role in synaptic regulation, via influencing AMPAR trafficking and stability.

Regulation of AMPAR abundance and trafficking at the postsynaptic membrane represents an important means in the regulation of synaptic strength and experience-dependent plasticity (Dingledine et al., 1999; Barry and Ziff, 2002; Malinow and Malenka, 2002; Sheng and Kim, 2002; Song and Huganir, 2002; Bredt and Nicoll, 2003; Collingridge et al., 2004; Mayer and Armstrong, 2004). Receptor trafficking is a complex process, often involving the interplay of more than one biological mechanism to achieve a net gain or loss of AMPARs at synaptic sites, including receptor insertion, internalization, and lateral diffusion at plasma membrane. In our study, we find that EAAT inhibition triggers a rapid internalization of AMPARs through NR2B-dependent activity. Thus, although alterations in other trafficking modalities cannot be completely ruled out, receptor internalization seems to be the major underlying mechanism for reduced receptor surface expression.

The reduction in AMPAR abundance after glutamate transport inhibition could result from reduced protein synthesis and/or elevated protein degradation. Given that receptor reduction can be detected within 30 min of EAAT suppression, changes in protein synthesis may not have a significant role. AMPARs have been shown to be degraded through both lysosome- and proteasome-dependent pathways (Ehlers, 2000; Patrick et al., 2003; Bingol and Schuman, 2005; Zhang et al., 2009; Schwarz et al., 2010; Lin et al., 2011). Our results indicate a requirement of the UPS in AMPAR removal during glutamate transporter inhibition. We find that proteasomal but not lysosomal inhibitors block TBOA-induced GluA1 degradation. Furthermore, in agreement with previous studies that demonstrated the conjugation of multiple ubiquitin moieties onto AMPAR subunits (Rezvani et al., 2007; Schwarz et al., 2010; Lin et al., 2011; Lussier et al., 2011), we find that the GluA1 shifts into a smear to as large as $250 \mathrm{kDa}$, which is substantially enhanced by TBOA treatment, consistent with polyubiquitination of the GluA1 receptors. Furthermore, we observed a decrease in AMPAR levels in wild-type, but not the lysine mutant, GluA1, suggesting that the TBOA effects are mediated through C-terminal ubiquitination of GluA1. In the future, it will be of interest to understand the cascade that links NR2B signaling to UPS function. In addition, we show that, when surface GluA1-containing receptors are prelabeled with an $\mathrm{N}$-terminal antibody, transporter inhibition leads to reduction in prelabeled receptor levels, suggesting that surface-localized receptors may be selectively targeted for degradation after their internalization.

The observed mechanisms may be involved in the regulation of synaptic function and plasticity. Reduction in synaptic AMPAR accumulation is expected to weaken synaptic efficacy, leading to synaptic depression. Indeed, AMPAR internalization and its dependency on NR2B-NMDAR activity reflects certain similarities to the induction of long-term depression (LTD). Consistently, it has been shown that glutamate reuptake inhibition facilitates the expression of LTD when paired with lowfrequency stimulation (Massey et al., 2004). EAAT-dependent downregulation on AMPAR expression may be implicated in pathological conditions. For instance, the elevated calcium transients that contribute to excitotoxicity arise from NMDARs as well as AMPARs (Cull-Candy et al., 2006; Beattie et al., 2010; Vieira et al., 2010), most notably through GluA2-lacking AMPARs (Man, 2011). It is possible that, during conditions when EAAT dysfunction leads to glutamate accumulation, a reduction in AMPAR and NMDAR abundance may serve as a protective mechanism to avoid receptor overexcitation (Yuen et al., 2007). Alternatively, neurons may sense glutamate synaptic spillover as a signal of abnormal overexcitation, which may trigger a homeostatic downregulation of AMPAR amount to reset the synaptic activity to basal levels (O’Brien et al., 1998; Turrigiano et al., 1998; Shepherd and Huganir, 2007).

We find that the neuronal transporter EAAT3 plays a key role in AMPAR distribution and turnover. Although glial transporters are believed to be responsible for most of glutamate removal, the importance of neuronal transporters has only been recognized recently (Scimemi et al., 2009; Li et al., 2010; Li and Zuo, 2011; Ross et al., 2011). In certain brain regions such as hippocampus and cerebral cortex, a large number of synapses are not surrounded by glial processes, suggesting a role of neuronal transporters in glutamate uptake and synaptic function (Ventura and Harris, 1999). In our preparation, in which neurons and dendrites are often located in areas free from glia or when glia are eliminated from the culture, EAAT inhibition still causes AMPAR reduction at synaptic sites, an effect that is mimicked by EAAT3 knockdown. This strongly indicates the requirement of 
neuronal glutamate transporter function for AMPAR synaptic stability. Indeed, neuronal transporters are implicated in multiple forms of neuropathological conditions and disorders. Knockdown of EAAT3 expression in adult mice results in progressive motor impairment in approximately half of the subject population and epileptic seizures in nearly all EAAT3 knockdown mice (Rothstein et al., 1996). These findings were supported by additional studies indicating that knockdown of EAAT3 resulted in both epilepsy and limbic hyperexcitability (Sepkuty et al., 2002; Mathews and Diamond, 2003). Furthermore, studies have demonstrated the accumulation of detergent-insoluble EAAT3 in the hippocampus of patients with Alzheimer's disease (Duerson et al., 2009), a neurodegenerative disorder that has a marked decrease in AMPAR levels during its early onset and progression (Chang et al., 2006; Hsieh et al., 2006). In addition, altered expression levels of the EAAT3 mRNA transcript and protein levels are observed in postmortem brain tissue from individuals with schizophrenia (McCullumsmith and Meador-Woodruff, 2002; Huerta et al., 2006; Lang et al., 2007), after seizure activity (Ross et al., 2011) and epilepsy (Mathern et al., 1999; Simantov et al., 1999; Crino et al., 2002; Proper et al., 2002; Rakhade and Loeb, 2008). Consistently, a net loss of synaptic AMPARs has been observed to accompany both epilepsy (Menuz and Nicoll, 2008) and schizophrenia (Meador-Woodruff and Healy, 2000; Hammond et al., 2010; Corti et al., 2011). It will be interesting to explore any relationship between changes in glutamate transporters and the downregulation of AMPARs in the development of these pathologies.

\section{References}

Adesnik H, Nicoll RA, England PM (2005) Photoinactivation of native AMPA receptors reveals their real-time trafficking. Neuron 48:977-985.

Arriza JL, Fairman WA, Wadiche JI, Murdoch GH, Kavanaugh MP, Amara SG (1994) Functional comparisons of three glutamate transporter subtypes cloned from human motor cortex. J Neurosci 14:5559-5569.

Ashby MC, De La Rue SA, Ralph GS, Uney J, Collingridge GL, Henley JM (2004) Removal of AMPA receptors (AMPARs) from synapses is preceded by transient endocytosis of extrasynaptic AMPARs. J Neurosci 24:5172-5176.

Barry MF, ZiffEB (2002) Receptor trafficking and the plasticity of excitatory synapses. Curr Opin Neurobiol 12:279-286.

Beattie MS, Ferguson AR, Bresnahan JC (2010) AMPA-receptor trafficking and injury-induced cell death. Eur J Neurosci 32:290-297.

Bingol B, Schuman EM (2005) Synaptic protein degradation by the ubiquitin proteasome system. Curr Opin Neurobiol 15:536-541.

Borgdorff AJ, Choquet D (2002) Regulation of AMPA receptor lateral movements. Nature 417:649-653.

Bredt DS, Nicoll RA (2003) AMPA receptor trafficking at excitatory synapses. Neuron 40:361-379.

Burbea M, Dreier L, Dittman JS, Grunwald ME, Kaplan JM (2002) Ubiquitin and AP180 regulate the abundance of GLR-1 glutamate receptors at postsynaptic elements in C. elegans. Neuron 35:107-120.

Chang EH, Savage MJ, Flood DG, Thomas JM, Levy RB, Mahadomrongkul V, Shirao T, Aoki C, Huerta PT (2006) AMPA receptor downscaling at the onset of Alzheimer's disease pathology in double knockin mice. Proc Natl Acad Sci U S A 103:3410-3415.

Chaudhry FA, Lehre KP, van Lookeren Campagne M, Ottersen OP, Danbolt NC, Storm-Mathisen J (1995) Glutamate transporters in glial plasma membranes: highly differentiated localizations revealed by quantitative ultrastructural immunocytochemistry. Neuron 15:711-720.

Collingridge GL, Isaac JT, Wang YT (2004) Receptor trafficking and synaptic plasticity. Nat Rev Neurosci 5:952-962.

Corti C, Xuereb JH, Crepaldi L, Corsi M, Michielin F, Ferraguti F (2011) Altered levels of glutamatergic receptors and $\mathrm{Na}^{+} / \mathrm{K}^{+}$ATPase-alphal in the prefrontal cortex of subjects with schizophrenia. Schizophr Res 128:7-14.
Crino PB, Jin H, Shumate MD, Robinson MB, Coulter DA, Brooks-Kayal AR (2002) Increased expression of the neuronal glutamate transporter (EAAT3/EAAC1) in hippocampal and neocortical epilepsy. Epilepsia 43:211-218.

Cull-Candy S, Kelly L, Farrant M (2006) Regulation of $\mathrm{Ca}^{2+}$-permeable AMPA receptors: synaptic plasticity and beyond. Curr Opin Neurobiol 16:288-297.

Derkach VA, Oh MC, Guire ES, Soderling TR (2007) Regulatory mechanisms of AMPA receptors in synaptic plasticity. Nat Rev Neurosci 8:101-113.

Diamond JS (2001) Neuronal glutamate transporters limit activation of NMDA receptors by neurotransmitter spillover on CA1 pyramidal cells. J Neurosci 21:8328-8338.

Diamond JS, Jahr CE (1995) Asynchronous release of synaptic vesicles determines the time course of the AMPA receptor-mediated EPSC. Neuron 15:1097-1107.

Dingledine R, Borges K, Bowie D, Traynelis SF (1999) The glutamate receptor ion channels. Pharmacol Rev 51:7-61.

Duerson K, Woltjer RL, Mookherjee P, Leverenz JB, Montine TJ, Bird TD, Pow DV, Rauen T, Cook DG (2009) Detergent-insoluble EAAC1/ EAAT3 aberrantly accumulates in hippocampal neurons of Alzheimer's disease patients. Brain Pathol 19:267-278.

Ehlers MD (2000) Reinsertion or degradation of AMPA receptors determined by activity-dependent endocytic sorting. Neuron 28:511-525.

Ehlers MD, Heine M, Groc L, Lee MC, Choquet D (2007) Diffusional trapping of GluR1 AMPA receptors by input-specific synaptic activity. Neuron 54:447-460.

Eroglu C, Barres BA (2010) Regulation of synaptic connectivity by glia. Nature 468:223-231.

Groc L, Heine M, Cognet L, Brickley K, Stephenson FA, Lounis B, Choquet D (2004) Differential activity-dependent regulation of the lateral mobilities of AMPA and NMDA receptors. Nat Neurosci 7:695-696.

Groc L, Choquet D, Stephenson FA, Verrier D, Manzoni OJ, Chavis P (2007) NMDA receptor surface trafficking and synaptic subunit composition are developmentally regulated by the extracellular matrix protein Reelin. J Neurosci 27:10165-10175.

Hammond JC, McCullumsmith RE, Funk AJ, Haroutunian V, MeadorWoodruff JH (2010) Evidence for abnormal forward trafficking of AMPA receptors in frontal cortex of elderly patients with schizophrenia. Neuropsychopharmacology 35:2110-2119.

Harada J, Sugimoto M (1999) An inhibitor of p38 and JNK MAP kinases prevents activation of caspase and apoptosis of cultured cerebellar granule neurons. Jpn J Pharmacol 79:369-378.

He Y, Janssen WG, Rothstein JD, Morrison JH (2000) Differential synaptic localization of the glutamate transporter EAAC1 and glutamate receptor subunit GluR2 in the rat hippocampus. J Comp Neurol 418:255-269.

He Y, Hof PR, Janssen WG, Rothstein JD, Morrison JH (2001) Differential synaptic localization of GluR2 and EAAC1 in the macaque monkey entorhinal cortex: a postembedding immunogold study. Neurosci Lett 311:161-164.

Heine M, Groc L, Frischknecht R, Béïque JC, Lounis B, Rumbaugh G, Huganir RL, Cognet L, Choquet D (2008) Surface mobility of postsynaptic AMPARs tunes synaptic transmission. Science 320:201-205.

Hou Q, Zhang D, Jarzylo L, Huganir RL, Man HY (2008) Homeostatic regulation of AMPA receptor expression at single hippocampal synapses. Proc Natl Acad Sci U S A 105:775-780.

Hsieh H, Boehm J, Sato C, Iwatsubo T, Tomita T, Sisodia S, Malinow R (2006) AMPAR removal underlies Abeta-induced synaptic depression and dendritic spine loss. Neuron 52:831-843.

Huerta I, McCullumsmith RE, Haroutunian V, Giménez-Amaya JM, Meador-Woodruff JH (2006) Expression of excitatory amino acid transporter interacting protein transcripts in the thalamus in schizophrenia. Synapse 59:394-402.

Izumi Y, Tokuda K, Zorumski CF (2008) Long-term potentiation inhibition by low-level $\mathrm{N}$-methyl-D-aspartate receptor activation involves calcineurin, nitric oxide, and p38 mitogen-activated protein kinase. Hippocampus 18:258-265.

Jabaudon D, Shimamoto K, Yasuda-Kamatani Y, Scanziani M, Gähwiler BH, Gerber U (1999) Inhibition of uptake unmasks rapid extracellular turn- 
over of glutamate of nonvesicular origin. Proc Natl Acad Sci U S A 96:8733-8738.

Lang UE, Puls I, Muller DJ, Strutz-Seebohm N, Gallinat J (2007) Molecular mechanisms of schizophrenia. Cell Physiol Biochem 20:687-702.

Lau CG, Zukin RS (2007) NMDA receptor trafficking in synaptic plasticity and neuropsychiatric disorders. Nat Rev Neurosci 8:413-426.

Li L, Zuo Z (2011) Glutamate transporter type 3 knockout reduces brain tolerance to focal brain ischemia in mice. J Cereb Blood Flow Metab 31:1283-1292.

Li X, Valencia A, Sapp E, Masso N, Alexander J, Reeves P, Kegel KB, Aronin N, Difiglia M (2010) Aberrant Rab11-dependent trafficking of the neuronal glutamate transporter EAAC1 causes oxidative stress and cell death in Huntington's disease. J Neurosci 30:4552-4561.

Lin A, Hou Q, Jarzylo L, Amato S, Gilbert J, Shang F, Man HY (2011) Nedd4-mediated AMPA receptor ubiquitination regulates receptor turnover and trafficking. J Neurochem 119:27-39.

Liu L, Wong TP, Pozza MF, Lingenhoehl K, Wang Y, Sheng M, Auberson YP, Wang YT (2004) Role of NMDA receptor subtypes in governing the direction of hippocampal synaptic plasticity. Science 304:1021-1024.

Lozovaya NA, Grebenyuk SE, Tsintsadze TSh, Feng B, Monaghan DT, Krishtal OA (2004) Extrasynaptic NR2B and NR2D subunits of NMDA receptors shape "superslow" afterburst EPSC in rat hippocampus. J Physiol 558:451-463.

Lussier MP, Nasu-Nishimura Y, Roche KW (2011) Activity-dependent ubiquitination of the AMPA receptor subunit GluA2. J Neurosci 31:3077-3081.

Malenka RC (2003) Synaptic plasticity and AMPA receptor trafficking. Ann N Y Acad Sci 1003:1-11.

Malinow R, Malenka RC (2002) AMPA receptor trafficking and synaptic plasticity. Annu Rev Neurosci 25:103-126.

Man HY (2011) GluA2-lacking, calcium-permeable AMPA receptors-inducers of plasticity? Curr Opin Neurobiol 21:291-298.

Man HY, Sekine-Aizawa Y, Huganir RL (2007) Regulation of \{alpha\}amino-3-hydroxy-5-methyl-4-isoxazolepropionic acid receptor trafficking through PKA phosphorylation of the Glu receptor 1 subunit. Proc Natl Acad Sci U S A 104:3579-3584.

Massey PV, Johnson BE, Moult PR, Auberson YP, Brown MW, Molnar E, Collingridge GL, Bashir ZI (2004) Differential roles of NR2A and NR2B-containing NMDA receptors in cortical long-term potentiation and long-term depression. J Neurosci 24:7821-7828.

Mathern GW, Mendoza D, Lozada A, Pretorius JK, Dehnes Y, Danbolt NC, Nelson N, Leite JP, Chimelli L, Born DE, Sakamoto AC, Assirati JA, Fried I, Peacock WJ, Ojemann GA, Adelson PD (1999) Hippocampal GABA and glutamate transporter immunoreactivity in patients with temporal lobe epilepsy. Neurology 52:453-472.

Mathews GC, Diamond JS (2003) Neuronal glutamate uptake contributes to GABA synthesis and inhibitory synaptic strength. J Neurosci 23:2040-2048.

Mayer ML, Armstrong N (2004) Structure and function of glutamate receptor ion channels. Annu Rev Physiol 66:161-181.

McCormack SG, Stornetta RL, Zhu JJ (2006) Synaptic AMPA receptor exchange maintains bidirectional plasticity. Neuron 50:75-88.

McCullumsmith RE, Meador-Woodruff JH (2002) Striatal excitatory amino acid transporter transcript expression in schizophrenia, bipolar disorder, and major depressive disorder. Neuropsychopharmacology 26:368-375.

Meador-Woodruff JH, Healy DJ (2000) Glutamate receptor expression in schizophrenic brain. Brain Res Brain Res Rev 31:288-294.

Mennerick S, Zorumski CF (1994) Glial contributions to excitatory neurotransmission in cultured hippocampal cells. Nature 368:59-62.

Menuz K, Nicoll RA (2008) Loss of inhibitory neuron AMPA receptors contributes to ataxia and epilepsy in stargazer mice. J Neurosci 28:10599-10603.

O'Brien RJ, Kamboj S, Ehlers MD, Rosen KR, Fischbach GD, Huganir RL (1998) Activity-dependent modulation of synaptic AMPA receptor accumulation. Neuron 21:1067-1078.

Patrick GN, Bingol B, Weld HA, Schuman EM (2003) Ubiquitin-mediated proteasome activity is required for agonist-induced endocytosis of GluRs. Curr Biol 13:2073-2081.

Peghini P, Janzen J, Stoffel W (1997) Glutamate transporter EAAC-1deficient mice develop dicarboxylic aminoaciduria and behavioral abnormalities but no neurodegeneration. EMBO J 16:3822-3832.
Pfrieger FW (2009) Roles of glial cells in synapse development. Cell Mol Life Sci 66:2037-2047

Pines G, Danbolt NC, Bjørås M, Zhang Y, Bendahan A, Eide L, Koepsell H, Storm-Mathisen J, Seeberg E, Kanner BI (1992) Cloning and expression of a rat brain L-glutamate transporter. Nature 360:464-467.

Proper EA, Hoogland G, Kappen SM, Jansen GH, Rensen MG, Schrama LH, van Veelen CW, van Rijen PC, van Nieuwenhuizen O, Gispen WH, de Graan PN (2002) Distribution of glutamate transporters in the hippocampus of patients with pharmaco-resistant temporal lobe epilepsy. Brain 125:32-43.

Prybylowski K, Chang K, Sans N, Kan L, Vicini S, Wenthold RJ (2005) The synaptic localization of NR2B-containing NMDA receptors is controlled by interactions with PDZ proteins and AP-2. Neuron 47:845-857.

Rakhade SN, Loeb JA (2008) Focal reduction of neuronal glutamate transporters in human neocortical epilepsy. Epilepsia 49:226-236.

Rezvani K, Teng Y, Shim D, De Biasi M (2007) Nicotine regulates multiple synaptic proteins by inhibiting proteasomal activity. J Neurosci 27:10508-10519.

Ross JR, Porter BE, Buckley PT, Eberwine JH, Robinson MB (2011) mRNA for the EAAC1 subtype of glutamate transporter is present in neuronal dendrites in vitro and dramatically increases in vivo after a seizure. Neurochem Int 58:366-375.

Rothstein JD, Martin L, Levey AI, Dykes-Hoberg M, Jin L, Wu D, Nash N, Kuncl RW (1994) Localization of neuronal and glial glutamate transporters. Neuron 13:713-725.

Rothstein JD, Dykes-Hoberg M, Pardo CA, Bristol LA, Jin L, Kuncl RW, Kanai Y, Hediger MA, Wang Y, Schielke JP, Welty DF (1996) Knockout of glutamate transporters reveals a major role for astroglial transport in excitotoxicity and clearance of glutamate. Neuron 16:675-686.

Rouse J, Cohen P, Trigon S, Morange M, Alonso-Llamazares A, Zamanillo D, Hunt T, Nebreda AR (1994) A novel kinase cascade triggered by stress and heat shock that stimulates MAPKAP kinase- 2 and phosphorylation of the small heat shock proteins. Cell 78:1027-1037.

Sanz-Clemente A, Matta JA, Isaac JT, Roche KW (2010) Casein kinase 2 regulates the NR2 subunit composition of synaptic NMDA receptors. Neuron 67:984-996.

Schwarz LA, Hall BJ, Patrick GN (2010) Activity-dependent ubiquitination of GluA1 mediates a distinct AMPA receptor endocytosis and sorting pathway. J Neurosci 30:16718-16729.

Scimemi A, Tian H, Diamond JS (2009) Neuronal transporters regulate glutamate clearance, NMDA receptor activation, and synaptic plasticity in the hippocampus. J Neurosci 29:14581-14595.

Sepkuty JP, Cohen AS, Eccles C, Rafiq A, Behar K, Ganel R, Coulter DA, Rothstein JD (2002) A neuronal glutamate transporter contributes to neurotransmitter GABA synthesis and epilepsy. J Neurosci 22:6372-6379.

Sheng M, Hyoung Lee S (2003) AMPA receptor trafficking and synaptic plasticity: major unanswered questions. Neurosci Res 46:127-134.

Sheng M, Kim MJ (2002) Postsynaptic signaling and plasticity mechanisms. Science 298:776-780.

Shepherd JD, Huganir RL (2007) The cell biology of synaptic plasticity: AMPA receptor trafficking. Annu Rev Cell Dev Biol 23:613-643.

Shimamoto K, Lebrun B, Yasuda-Kamatani Y, Sakaitani M, ShigeriY, Yumoto N, Nakajima T (1998) DL-threo-beta-benzyloxyaspartate, a potent blocker of excitatory amino acid transporters. Mol Pharmacol 53:195-201.

Simantov R, Crispino M, Hoe W, Broutman G, Tocco G, Rothstein JD, Baudry M (1999) Changes in expression of neuronal and glial glutamate transporters in rat hippocampus following kainate-induced seizure activity. Brain Res Mol Brain Res 65:112-123.

Song I, Huganir RL (2002) Regulation of AMPA receptors during synaptic plasticity. Trends Neurosci 25:578-588.

Storck T, Schulte S, Hofmann K, Stoffel W (1992) Structure, expression, and functional analysis of a $\mathrm{Na}^{+}$-dependent glutamate/aspartate transporter from rat brain. Proc Natl Acad Sci U S A 89:10955-10959.

Tanaka K, Watase K, Manabe T, Yamada K, Watanabe M, Takahashi K, Iwama H, Nishikawa T, Ichihara N, Kikuchi T, Okuyama S, Kawashima N, Hori S, Takimoto M, Wada K (1997) Epilepsy and exacerbation of brain injury in mice lacking the glutamate transporter GLT-1. Science 276:1699-1702

Tardin C, Cognet L, Bats C, Lounis B, Choquet D (2003) Direct imaging of lateral movements of AMPA receptors inside synapses. EMBO J 22:4656-4665. 
Tong G, Jahr CE (1994) Block of glutamate transporters potentiates postsynaptic excitation. Neuron 13:1195-1203.

Turrigiano GG, Leslie KR, Desai NS, Rutherford LC, Nelson SB (1998) Activity-dependent scaling of quantal amplitude in neocortical neurons. Nature 391:892-896.

Ullian EM, Christopherson KS, Barres BA (2004) Role for glia in synaptogenesis. Glia 47:209-216.

Ventura R, Harris KM (1999) Three-dimensional relationships between hippocampal synapses and astrocytes. J Neurosci 19:6897-6906.

Vieira M, Fernandes J, Burgeiro A, Thomas GM, Huganir RL, Duarte CB, Carvalho AL, Santos AE (2010) Excitotoxicity through $\mathrm{Ca}^{2+}$-permeable AMPA receptors requires $\mathrm{Ca}^{2+}$-dependent JNK activation. Neurobiol Dis 40:645-655.
Yashiro K, Philpot BD (2008) Regulation of NMDA receptor subunit expression and its implications for LTD, LTP, and metaplasticity. Neuropharmacology 55:1081-1094.

Yi JJ, Ehlers MD (2007) Emerging roles for ubiquitin and protein degradation in neuronal function. Pharmacol Rev 59:14-39.

Yuen EY, Gu Z, Yan Z (2007) Calpain regulation of AMPA receptor channels in cortical pyramidal neurons. J Physiol 580:241-254.

Zhang D, Hou Q, Wang M, Lin A, Jarzylo L, Navis A, Raissi A, Liu F, Man HY (2009) Na,K-ATPase activity regulates AMPA receptor turnover through proteasome-mediated proteolysis. J Neurosci 29:4498-4511.

Zhu JJ, Qin Y, Zhao M, Van Aelst L, Malinow R (2002) Ras and Rap control AMPA receptor trafficking during synaptic plasticity. Cell 110: 443-455. 